\title{
Facilities Management Practices in Malaysia: A Literature Review
}

\author{
Nordiana Mohd Isa1,a , Syahrul Nizam Kamaruzzaman¹, Othman Mohamed ${ }^{1}$, Aini Jaapar ${ }^{2}$ and Asra Zaliza Asbollah ${ }^{1}$ \\ ${ }^{1}$ Department of Building Surveying, Faculty of Built Environment, Universiti Malaya, Kuala Lumpur. Malaysia. \\ ${ }^{2}$ Faculty of Architecture, Planning and Surveying, Universiti Teknologi MARA, Shah Alam, Selangor. D.E. Malaysia.
}

\begin{abstract}
Facilities management in Malaysia has been practiced for decades. The development of its formal practice parallels the improvement of the built environment in the nation. Involvement of the public and private sectors teaming up in arranging the National Asset and Facilities Management (NAFAM) in demonstrates the vital collaboration in the facilities management area in Malaysia. Facilities management is seen distinctively as indicated by diverse geographical locations, interests and schools of thought. Facilities management is delegated a service-based industry which gives proficient counsel and administration of clients' building facilities including residential, commercial, industrial, airports terminals and offices. The aim of this paper is to review the gaps that exist, especially on how FM is being practice in comparison with the published FM body of knowledge. Very relying upon literature, this paper discovered a gap that is an unclear description of current FM applications. This research aims to give new bits of knowledge to upgrade comprehension of FM execution in Malaysia.
\end{abstract}

Keywords: Facilities management, definition, Malaysia, and practices.

\section{Introduction}

Started in the 1980s, a new and more incorporating management speciality has developed, focusing on facilities that, people increasingly recognized the importance of managing not only buildings but also such buildings in connection with people, integrating with the principles of administration and development process. Current developments in information technology, advancements in telecommunications and the removal of trade barriers, are among the factors transforming the world of facilities management all over the world and in turns have spread the needs of facilities management from outside into Malaysia.

In parallel, facilities management over the past thirty years has been established as a profession with a number of worldwide professional bodies supporting and accepting a significant number of facilities management practitioners. Since then, the understanding of facilities management is varied as different professions interpreted it differently. However, despite its diversity in the theory and practice, facilities management retains essential cores that maintain its identity that differentiate it from other professions [23]. Therefore, this paper aims to review the gaps that exist, especially on how FM is being practise in comparison with the published FM body of knowledge.

\section{Problem Statement}

The $10^{\text {th }}$ Malaysia Plan that was distributed in late 2010 states that the nation is presently looking towards a more service-oriented economy with a reduction in the manufacturing sector. Economic Planning Unit (EPU) states that the services sector possesses a $61 \%$ share of Malaysia's GDP against other sectors. For example, manufacturing, mining, construction and agriculture. According to [17], it can be deduced that facilities management is an imperative sector in the Malaysian Economy as a feature of the bigger share of the service sector. This draws attention and enthusiasm to research facilities management in the Malaysian context.

\section{Literature Review}

As depicted in the introduction, the overview of this paper reveals the idea of facilities management. By [24], challenges can emerge when a specific key term produce diverse meaning and importance to various individuals, that might likewise misinterpretation. In this way, characterizing essential keywords solicit in the ideas expresses a better comprehension of the theories.

\footnotetext{
${ }^{a}$ Corresponding author: diana_isa@um.edu.my
} 


\subsection{Definition of facilities management}

The facility management (FM) as an industry has emerged as one of the fastest growing sectors over the years. However, the scope and identity of FM are still unclear as evidenced by the definitions and issues that attempt to describe its scope. In fact, FM is the multi-disciplinary kind of work that covers a wide range of various activities, responsibilities, and knowledge. What is more interesting, every aspect of an organisation seems to be drawn into FM.

If the building is said to be one of the important things in real estate, facilities management is part of the management of the building that needs to be emphasized by the management body. One of the facilities management objectives is to reduce maintenance costs while maintaining quality or the quality of facilities provided. Rozilah Kasim [23] in her book stated that;

"The original concept of facilities management is very much associated with its role as "enabler' to support the core business of the organisations with the primary aim of minimising costs and maximising profit along the delivery process. Early understanding has seen facilities management as a coordinating function that integrates between people, place, process, and technology. This conventional function has a three-way interface between organisational culture, the people, and physical assets. This interface, somehow or rather, has created the original demand for facilities management services and expertise."

Efforts to define facility management in Malaysia cannot get away from starting by looking at the definitions that have been produced in the country earlier practice of this discipline. The International Facility Management Association (IFMA) as the official definition of the profession Manager Facilities in the United States and in the United Kingdom, British Institute of Facilities Management (IFM) uses the following definition. Countries such as Singapore and Hong Kong and most of other countries in Asia have adopted the same definition which was initiated by IFMA:

"Facilities Management is the integration of multi-disciplinary activities within the built environment and the management of their impact upon people and the workplace".

By definition, FM is a process that requires a multiskills approach that supports the core business of the organisations by interfacing the physical workplace and people [5]. This in accordance, shows that FM acts as a support role or service, some part served the needs of primary activities or core business (demand side) and the other part is the organisation's non-core business (supply side) [27]. The function of FM is also to reconcile, through time, these demand and supply aspects of the organization. In other words, FM should integrate knowledge of both facilities and management in order to work effectively. Successful FM leads to workplaces which better support the flow of productive processes while adding value and reducing costs. The scope, range of services, activities, responsibilities, skills and knowledge of facility management are all intended to better integrate existing organisational factors.

In particular, FM can be described as managing the physical and non-physical facilities and unpredictable business requirements. It is required by all professionals who undertake the management to achieve business goals. From a technical standpoint, facilities management and responsibilities include work that was originally done by architects, landscape architects, interior designers, civil engineering, building surveying, valuation, quantity surveying and etc. In addition, among the items included in FM is expert advice, the conservation of the building, building renovation, building cleaning, security, parking, electricity, telephone, fire suppression system, air conditioning, elevators, landscaping and other facilities are available in the building.

To gain a better comprehension of the terms, the description and definition of facilities management were presents as per Table 1 .

\begin{tabular}{|l|l|}
\hline Source & Definition / Description \\
\hline Becker, [6] & $\begin{array}{l}\text { FM is responsible for } \\
\text { coordinating all efforts related to } \\
\text { planning, designing and } \\
\text { managing buildings and their } \\
\text { systems, equipment and furniture } \\
\text { to enhance the organisation's } \\
\text { ability to compete successfully in } \\
\text { a rapidly changing world. }\end{array}$ \\
\hline Bernard, [7] & $\begin{array}{l}\text { Defines facilities as "the premises } \\
\text { and services required to } \\
\text { accommodate and facilitate } \\
\text { business activity". Bearing this in } \\
\text { mind, to have any chance of being } \\
\text { fully cost effective the } \\
\text { management of facilities must } \\
\text { directly embrace the three generic } \\
\text { cost centres which include } \\
\text { premises, support services and } \\
\text { information technology. }\end{array}$ \\
\hline Alexander, [1] & $\begin{array}{l}\text { The scope of discipline covers all } \\
\text { aspects of property, space, } \\
\text { environmental control, health and } \\
\text { safety, and support services. }\end{array}$ \\
\hline Hinks \& McNay, & $\begin{array}{l}\text { Common interpretations of the } \\
\text { FM remit: maintenance } \\
\text { management; space management } \\
\text { and accommodation standards; } \\
\text { project management for new- } \\
\text { build and alterations; the general } \\
\text { premises management of the } \\
\text { building stock; and the } \\
\text { administration of associated } \\
\text { support services. }\end{array}$ \\
$\begin{array}{l}\text { The primary function of FM is } \\
\text { resource management, at strategic } \\
\text { and operational levels of support. } \\
\text { Generic types of resource } \\
\text { management central to the FM } \\
\text { function are the management of } \\
\text { financial resources, physical }\end{array}$ \\
\hline 12$]$
\end{tabular}




\begin{tabular}{|c|c|}
\hline & $\begin{array}{l}\text { resources, human resources, and } \\
\text { the management of resources of } \\
\text { information and knowledge. }\end{array}$ \\
\hline $\begin{array}{l}\text { Atkins \& } \text { Brooks, } \\
{[4]}\end{array}$ & $\begin{array}{l}\text { An integrated approach to } \\
\text { operating, maintaining, improving } \\
\text { and adapting the buildings and } \\
\text { infrastructures of an organisation } \\
\text { in order to create an environment } \\
\text { that strongly support the primary } \\
\text { objectives of the organisation. }\end{array}$ \\
\hline Amaratunga, [3] & $\begin{array}{l}\text { FM as "creating an environment } \\
\text { that is conducive to carrying out } \\
\text { the organisation's primary } \\
\text { operations, taking an integrated } \\
\text { view of the services infrastructure } \\
\text { and using this to deliver customer } \\
\text { satisfaction and value for money } \\
\text { through support for enhancement } \\
\text { of the core business". }\end{array}$ \\
\hline IFMA, [13] & $\begin{array}{l}\text { Facilities must be managed as an } \\
\text { integrated system. The } \\
\text { International Facility } \\
\text { Management Association defines } \\
\text { facility management as the } \\
\text { practices of coordinating the } \\
\text { physical workplace with the } \\
\text { people and work of the } \\
\text { organization. }\end{array}$ \\
\hline BIFM, [8] & $\begin{array}{l}\text { An integration of multi- } \\
\text { disciplinary activities within the } \\
\text { built environment and } \\
\text { management of their impact upon } \\
\text { people and the workplace. }\end{array}$ \\
\hline IFMA, [14] & $\begin{array}{l}\text { FM is "a profession that } \\
\text { encompasses multiple disciplines } \\
\text { to ensure functionality of the built } \\
\text { environment by integrating } \\
\text { people, place and process, and } \\
\text { technology" }\end{array}$ \\
\hline IFMA, [15] & $\begin{array}{l}\text { FM is a profession that } \\
\text { encompasses multiple disciplines } \\
\text { to ensure functionality of the built } \\
\text { environment by integrating } \\
\text { people, place, process and } \\
\text { technology. }\end{array}$ \\
\hline BIFM, [9] & $\begin{array}{l}\text { FM is the integration of processes } \\
\text { within an organisation to maintain } \\
\text { and develop the agreed services } \\
\text { which support and improve the } \\
\text { effectiveness of its primary } \\
\text { activities. }\end{array}$ \\
\hline
\end{tabular}

Table 1: Summary of the definition of 'facilities management'

According to Abd Rahman [2], facilities management is divided into 3 major components such as property, equipment and services for which it depends on the respective management to manage and provide the facility to the users. He added, the scope of facility management includes a number of areas such as:

i. Management and maintenance of buildings

ii. Maintenance engineering

iii. Service building

iv. Project management renovation and conservation

v. Management space

vi. Provision of security and cleaning

vii. Offices and food service

viii. Negotiate contracts and purchases

ix. Revision rent

x. Negotiating leases and lease relations

xi. Information technology

xii. Planning for the future portfolio

Beforehand, according to Pheng [21], FM contains four main principles:

i. The continuously programme coordination of all efforts, namely planning, designing, construction and management of facilities towards enhancing the working environment for the people and the organization's ability to meet its business objectives;

ii. The total integration of a diverse field of disciplines of business, architecture, behavioural and engineering science under one entity in an organization to oversee all facilities functions previously controlled by independent departments;

iii. The management of activities proactively rather than the management of facilities reactively; and

iv. A business concept where FM policies and procedures are guided by organizational goals and objectives as well as available resources.

To achieve all these 4 principles, there are three levels of facilities management strategy should be adopted in managing a facility, as stated by Abd Rahman [2]:

i. The strategy analysis - in this stage all the data and facts will be collected including the objective of the organization, policies, and requirements, resources, processes, physical asset conditions, use of space and function, as well as analysis of the costs involved.

ii. The completion strategy - the result of information collected in stages 1 , including the objectives of the organization will be evaluated and the analysis made for the 2nd time onwards facility management strategy will be established. This means that an organization should choose a real strategy.

iii. The implementation of the strategy - the stage of implementation, it consists of the development strategy through the realization of an implementation plan containing a timetable planning, such period or periods and complete risk management ... it includes human and labor and the system, communications, planning, and resources acquisition (procurement). 


\subsection{Integrated facilities management}

Facilities management as mentioned has been evolving as a multidisciplinary discipline. According to Kamaruzzaman \& Zawawi [25], the greater part of the Malaysian construction industry professional recommend that regularly FM just focusing on building administration after completion of any construction works. However, Jensen [16] claims that FM association has close relations with the fundamental operations of the association and it is not just routine maintenance towards work facilities and assets of the business. This is supported by W.S.Z, WanHamdan et al [28], which they point out that facilities management is key to practice in all areas. For example in the public sector, facilities management assumes an essential part in the improvement of socio-economic progress of a nation. This shows that people are starting to challenge the rigidity of professional traditions which support the individual practice, suggesting strongly that any professional should not be the exclusive professional in facilities management.

FM is relatively new in Malaysia, still at the infancy stage. Presently, the adoption and practice of FM are predominantly focused on MNCs and government agencies such as JKR. Other than that, FM is widely adopted in a single sector such as in healthcare sector. As stated by Syahrul Nizam and Emma Marinie [25], FM was firstly brought into Malaysia by such sector in 1997 which showed that the development of FM in Malaysia started only in the middle of 1990s. They added the government has played an important role in the development of FM in Malaysia. Syahrul Nizam and Emma Marinie [25] stated, "In 1996, the government has privatized the nonclinical support services in the government hospitals to three FM companies. It was indeed the biggest FM contract by the government at that time. It also marked the starting of the new era of FM in Malaysia". On top of that, the establishment of National Asset and Facility Management (NAFAM) shows that the government is very keen on the establishment of a systematic management. Moreover, Guidelines for the Management of Movable Assets and another act, the Building and Common Property (Maintenance and Management) Act 2007 Act 663, was circulated in 2007. This may be associated with a portion of one trillion ringgit Malaysia (RM) for public building facilities maintenance through Ninth Malaysian Plan in 2006. This funding also believed related to the articulation in 2001 by the Deputy Prime Minister Datuk Seri Abdullah Ahmad Badawi which he is expressing his concern about the need to redesign the quality level of public services [10].

Elyna Myeda Nik Pitt Michael [11] continues: "However, this act focuses only on the maintenance and management of residential or housing properties, particularly on the responsibilities of the managing agents and joint management body, and on maintenance funds. The year 2007 also marked the first involvement of the government in organising a national convention, the National Asset and Facility Management, in Kuala Lumpur. In the first quarter of 2009, the government launched the Government Asset Management Policy. This manual is more focused on the principles of government asset management, and no standards or specification on the FM services are outlined [22]. A system named mySPATA was also developed for the management of immovable assets [22]. All the government initiatives in providing guidelines, policies and manuals on service quality indicate that the government is slowly taking a step forward. However, no specific guideline on facilities management practice has yet been developed for both public and government sectors".

N.E.M. Nik-Mat et al. [19] however stated, FM in both private and public sector has been evolving only over the last 10-15 years. In this respects, some local practitioners associate it only with the professional maintenance of buildings. As compared to North America and Europe, the responsibility of the facility manager is covering project management construction and operation of physical facilities. In other words, the facilities management in that countries covering a wider field of management and services include the main activities of the organization. Even in the United Kingdom, this field including the practice of directly or indirectly relate to the needs and business goals of the organization.

Facility management practices in accordance, have great potential to grow and prosper in the construction industry in Malaysia. A number of physical development, undertaken by the size of a large development are among the factors that reflect the volume of the physical facilities should be managed. This scenario is the result of ongoing efforts by the government to build and develop the country. The service providers involved in the management of physical facilities (specialty consultants, contractors, suppliers of materials and equipment, etc.) can seize great opportunities that exist, particularly in terms of providing an integrated facilities management or comprehensive to local organizations.

\subsection{Facilities management in Malaysia}

In developed markets, FM administrations are firmly incorporated with some different administrations in the real estate sector, for example, rent collection and lease management. However in Malaysia demonstrating that the idea of FM has already not sufficiently developed to give complete property management practices. As mentioned, FM is the provision and management of resources, physical environment and business support services to complement the strategic and operational objectives of an organization, integrating key functions like processes and technologies with people, with the flexibility for future integration.

Management of a facilities required to increase the provision of facilities management to ensure the building is clean, safe and in a healthy environment. For example, which has been practiced in UITM, the Facilities 
Management Division is one of the main division, who's responsible for the overall maintenance of the building and the area around the campus. There are four units in Facilities Management Division, they are the Public Unit, the Assembly Unit (UAKM), Unit of Mechanical, and Electrical and Telecommunications Unit (UMET).

One of the examples of FM practices in Malaysia is in the office buildings. Syahrul Nizam and Emma Marinie [25], in their study, mentioned that this kind of building normally would have their own management team to monitor the conditions of buildings. This management team usually lead by maintenance or building managers. Maintenance, cleaning, landscaping, lightings, heating, ventilating and air conditioning (HVAC), lift or escalators, mechanical and electrical, sanitary and plumbing, access, signage, parking and others are among the services provided by building managers [19].

Another example is managing a sports facility which is now gaining popularity in the operating system of the building in Malaysia. The scope of facility management refers not only to the management of sports facilities but also consists of various types of related elements and buildings. FM as Teicholz and Noferi [26] suggest, encompasses a broad range of joint activities which are not limited only to one area such as planning or design or leasing, project management, asset management or construction or even marketing facilities and acquisition of assets.

Each FM varies based on the size, composition and management structure of the facilities involved. For example, typically most of the sports facilities built in Malaysia is managed by the Local Authority (PBT) or State Stadium Corporation who are not profit-oriented. The facilities are designed and built is considered to represent the aspirations of the government to provide the best facilities for the community. In addition, the main focus in the management of the facility is to ensure that each piece of equipment can operate properly, safe and functional as required by the user. As a facilities manager, the focus will be centred on how to ensure facilities operate smoothly by matching with a variety of equipment, tools, and mechanisms that felt best for the consumer and managed facilities. However, large facilities managers often focus their time on the commercial use of facilities such as market rents for commercial space and generate profits.

Rivalry in Malaysian FM services market is exceptional with the vicinity of both local and worldwide service providers. The business sector is required to witness more rivalry from new contestants through mergers and acquisitions. Subsequent to the business sector is filled with minimal effort disorderly service providers, estimating and edges go under pressure. These disorderly players give services at low rates, leaving the competition from huge organized players. Nonetheless, much worldwide property administration organizations have made a raid into this business sector and have been accomplishing extraordinary development rates in the course of the most recent five years. Through the inorganic route, a couple of global property administration organisations have seen a sharp rise in the business sector by obtaining some local companies.

Facilities management in short is based on the requirements of the coordination between the facilities and consumers. It needs to be adjusted and balanced to meet the requirements. Various disciplines such as engineering, architecture, business management and behavioral science are needed to achieve the best facilities management as to guarantee a good quality facility management and effective. Accordingly, as the manager of a facility, it is not an easy task because it requires a manager to have the skills, expertise and extensive experience in managing and maintain a facility.

\section{Methodology}

This paper solely used the qualitative approach. The literature was collected and compiled from various publications and also previous research prior to the study area. Analytical review and synthesis have conducted in order to strengthen the gap of research from literature. The findings of literature will be strengthened through semi-structured interview involving FM experts. For this paper, the explanation of literature is only discussed because the study is still ongoing.

\section{Result of literature findings}

From the literature, only a few studies have considered the funding elements or issues in the implementation of FM specifically in the Malaysian context. As study done by Myzatul Aishah Kamarazaly et al. [18] showed "that the critical challenges currently facing the UFMs (Australasian university facilities managers) comprised issues relating to the following (in diminishing order of significance): inadequate funding, emergency management and business continuity planning, statutory compliance, sustainability and environmental stewardship, keeping up with rapid changes in technology, operational efficiency, identifying and meeting stakeholder needs, maintenance and manpower. Preparing for and responding to disaster/emergency was perceived as the most critical challenge of the future, perhaps, due to the recent natural disasters. Overall, poor funding was identified as the root of all other issues faced by the UFMs, hence suggested strategies for addressing the key challenges harped on financial improvement measures."

Other than that, past studies also have distinguished different elements compelling the accomplishment of key FM functions in many managerial levels in Malaysia context, the components, unfortunately, are not recorded as far as their relative levels of effect on the key FM functional areas. Myzatul Aishah Kamarazaly et al. [18] also stated that "Facilities managers would benefit from the prioritisation mainly due to the fact that it would enable them to leverage the limited resources at their disposal to address those factors that have a higher impact on the FM functional areas." Thus, it is expected that further study should fill this gap. 


\section{Significance/benefits of the study}

The topic presented in this paper show that like whatever another arrangement of experts, the facilities managers in Malaysia face numerous challenges both from internal and external that prevent the accomplishment of their vital objectives and commitment to the general institutional value. The study results are expected to be of advantage to any institutional facilities managers in Malaysia particularly in planning a proper reaction to the recognised problems.

\section{Conclusion}

Despite the current practice models identified locally facility, the FM practices are very much different from the models being practice in the United States and the United Kingdom (in particular). However, this discipline does not mean the opportunity is limited. As mentioned, FM ought to be gone for diminishing the general expense of upkeep and expanding the life of the asset or building. Factors such as absence of accessibility of technical and non-technical manpower, expanded lead times in assembling resources/staff after a project has been effectively contracted because of labour lack, an expansion in swelling and labour cost, and inadequate procurement of services at low rates by chaotic industry members were among the reason why in-house practiced nowadays. In parallel, not only in the mentioned agencies, but other such as libraries, railway stations, and airports is likewise anticipated that would intensify opportunities for the FM market.

In short, it can be mentioned that the future interest for FM is very enthusiastic. As the saying goes, 'As long as buildings exist, there will be a demand for facility management'. On the other hand, the challenge is to educate building owners as to the benefits of FM. The ultimate advantage of FM, i.e. value appreciation of the property, image and long-term cost, must be completely understood and increased in value by building owners for the industry to develop. In other words, building owners ought to have the capacity to see the long-term gain.

\section{Acknowledgement}

The authors would like to thank the funding bodies of this research: the University of Malaya under FRGS Project. No. FP025-2014B.

\section{References}

1. Alexander, K. (1996). Facilities Management: Theory and Practice. London \& New York: Taylor \& Francis Group

2. Abd Rahman Mohd Noor (2008). Pengurusan Hartanah Komersial dan Awam, Edisi Kedua, Leeds Publications, Petaling Jaya, Selangor
3. Amaratunga, D. et al. (2000) Assessment of facilities management performance - what next? Facilities, 18 $(1 / 2)$, pp. 66-75.

4. Atkin, B. and Brooks, A. (2000), Total Facilities Management, Blackwell Science, Oxford, U.K

5. Barrett, P (2004). Facilities Management: Towards Best Practice, Blackwell Science, London.

6. Becker, F. (1990), The Total Workplace, Van Nostrand Reinhold. New York, NY

7. Bernard WilliamsMay/June (1996): Cost-effective facilities management: a practical approach pp.2638

8. British Institute of Facilities Management (2003) British Institute of Facilities Management, Available at: http://www.bifm.org.uk

9. British Institute of Facilities Management (2011) British Institute of Facilities Management, Available at: http://www.bifm.org.uk

10. Construction Industrial Development Board (CIDB) (2010), Newsletter [on-line], Malaysia, Published by CIDB, available at: www.cidb.gov.my/v6/?q_en/content/533 (accessed December 2015).

11. Elyna Myeda Nik Pitt Michael (2014). Facilities management in Malaysia. Facilities. Vol. 32 (9/10), pp. $490-508$

12. Hinks, J. and McNay, P. (1999), "The creation of a management-by-variance tool for facilities management performance assessment", Facilities, Vol. 17 Nos 1/2, pp. 48-60.

13. IFMA (2003), Facts about the International Facility Management Association, available at: www.ifma.org

14. International Facilities Management Association (2008) International Facilities Management Association (IFMA), Available at: http://www.ifma.org

15. International Facilities Management Association (2011) International Facilities Management Association (IFMA), Available at: http://www.ifma.org

16. Jensen, P. A. (2011). Organisation of facilities management in relation to core business. Journal of Facilities Management. 9, pp. 78-95.

17. Mohd Fadzil Mat Yasin (2013). The contributions of knowledge mapping in facilities performance evaluation practice in Malaysia

18. Myzatul Aishah Kamarazaly, Jasper Mbachu and Robyn Phipps (2013). Challenges faced by facilities managers in the Australasian universities. Journal of Facilities Management. 11 (2), pp. 136 - 151

19. N.E.M. Nik-Mat et al. (2011). Assessing the Maintenance Aspect of Facilities Management through a Performance Measurement System: A Malaysian Case Study. Procedia Engineering. 20, pp. $329-338$

20. Nutt, B. (2000), "Four competing futures for facility management", Facilities, Vol. 18 Nos 3/4, pp. 124132. 
21.Pheng, L.S. (1996). Total Quality Facilities Management: A Framework for Implementation. Facilities. 14(5/6), 5-13.

22. Public Works Department Annual Report (2009), Public Works Department Annual Report, Malaysia, Published by PWD, available at: www.jkr.gov.my/jkr4/index.php?r_page/view\&id_1 61

23. Rozilah Kasim (2011). Community-based Facilities Management: Theory and Practices. Penerbit UTHM, Johor

24. S. Parmjit, Y. F. Chan, and K. S. Gurnam, A comprehensive guide to writing a research proposal. VentonPublishing, Batu Caves, Malaysia, 2006.

25. Syahrul Nizam Kamaruzzaman and Emma Marinie Ahmad Zawawi, (2010). Development of facilities management in Malaysia. Journal of Facilities Management. 8 (1), pp. $75-81$

26. Teicholz, E., and Noferi, C. (2002) 'Higher ED integrates CAFM better. Facilities Design and Management. 1, pp.13-14.

27. Wanlaya Patanapiradej (2006). The Scope of Facility Management. Nakhara. 6, p. 75-90

28. W.S.Z, Wan-Hamdan et al (2011). Contribution of Facilities Management Process in Supporting Malaysia National Higher Education Strategic Plan. Procedia Engineering, 20, p. 180-187 